\title{
Aeromycological profile of the public parks of Bhilai Township, Chhattisgarh, India
}

\author{
Pragya Kulkarni \\ Department of Botany and Microbiology, Govt. V.Y.T. P.G. (Auto.) College, Durg, (C.G.), India \\ pradnya.29469@yahoo.in
}

\begin{abstract}
A systematic aeromycological survey of four public parks of Bhilai Township in terms of sporal diversity and number was carried out during July 2009 to June 2010. A total of 22 genera of fungi having 37 species were recorded during the study period. Aeromycosporal diversity was maximum in the month of November (152) followed by October (148). Overall highest prevalence of fungal types was represented by Aspergillus (06 spp.) followed by Alternaria and Curvularia (04 spp. each) respectively. Aspergillus nigerwas found as most frequent $(91.66 \%)$ fungal species followed by Alternaria alternata (83.33\%). The highest percentage contribution (9.34\%) was observed for Alternaria alternata. Aeromycological data may be useful in terms of community health management and environment point of view.
\end{abstract}

Keywords: Aeromycology, public parks, Alternaria, Aspergillus, Curvularia, health

\section{Introduction}

The microflora of any habitat varies with host type, environmental condition and relations among them. Thus, the diversity of microflora differs from time to time and place to place. Accordingly, their impact may also vary resulting disease development in surrounding plants, deterioration of materials, fungal disorders and allergic responses to inhabitants in the form of skin sensitivity and hypersensitivity in sensitive individuals (Ganguly, 1992; Raha \& Bhattacharya, 1992; Singh et al., 1992; Singh \& Dorycanta, 1992; Tilak, 1998; Begum \& Ahmed, 2006; Verma \& Khare, 2009). Their continuous occurrence and recurrence at any site also provide required data to build up prediction models for forecasting epidemics (Rao, 1993).

Bhilai is an industrial township of Chhattisgarh, situated near Durg and known as steel city. As per the township norms there are public parks at regular intervals in between the residential sectors. The parks mostly consist of mixed tree plantations, grass lawns and places for recreation and playing. The area mainly receive tropical climate with very hot summer, moderate rainfall and short winters. The present investigation was undertaken to isolate and identify the most frequently distributed aeromycoflora over such areas of Bhilai Township.

\section{Materials and methods}

Observations were recorded at four public parks i.e. Steel club park, sector -8; Jubli park, sector-6; Jawahar Udyan, sector - 5 and Ambedkar park, sector -1 . The parks consists mainly of mixed tree plantation in the surroundings with the members of family Caesalpiniaceae: Cassia fistula, Bauhinia variegate Caesalpinia pulcherima and Delburgia sissu etc. Sterilized petri plates of $9 \mathrm{~cm}$ diameter containing rose bengal streptomycin potato dextrose agar and sabouraud agar medium were exposed for $10 \mathrm{~min}$ with replicates of 5 petri plates per site fortnightly during July 2009 - June 2010. The plates were kept at 12 inches above the ground in between 7-8 am for trapping of fungal flora on the basis of gravitational fall. The exposed plates were incubated in an inverted position at $28 \pm 1^{\circ} \mathrm{C}$ for $5-10 \mathrm{~d}$ for the growth of CFUs. Fungal colonies were identified on the basis of visual and microscopic structures as per the manual of soil fungi (Gilman, 1959), dematiaceous hyphomycetes (Ellis, 1971) and illustrated genera of Imperfect fungi (Barnett et al., 1972). Percentage frequency and percentage contribution of individual species were calculated as per standard formula:

No.of observations in which colony appear $\%$ Frequency $==$

Total no of observations recorded

Total number of colonies of all species

$\%$ Contribution $=-X 100$

Total number of colonies of one species

\section{Results and discussion}

Altogether 37 fungal species belonging to 22 genera were isolated from study sites during different sampling periods (Table 1). The total fungal species increased from July to Dec both qualitatively and quantitatively. But overall the spore count exhibited seasonal fluctuations. It was higher in between Oct, Nov and Dec and exhibit decreasing trend till June. Maximum fungi were isolated in the month of Oct and Nov in terms of number of CFUs (148 \& 152) respectively and least in the months of Feb and Mar (19 \& 18). Verma and Chile (1992) also reported greater variety and large number of aeromycoflora during May to Oct and least in Jan. This is generally attributed to favorable conditions for growth during the periods. Singh and Siddiqui (2009) have done similar work in polluted and unpolluted air zones and reported that the survival of air borne spores would depend on several factors like wind velocity, distance from source, time in air, relative humidity, gaseous composition of atmosphere, sunshine and species itself. Month-wise trend of species richness is depicted in Fig.1. It was observed that there is a peculiar trend of number of fungal species found in every 
Table 1. Distribution, \% frequency and \% contribution of Aeromycoflora at study sites

\begin{tabular}{|c|c|c|c|c|c|c|c|c|c|c|c|c|c|c|c|}
\hline Fungal Species & July & Aug & Sep & Oct & Nov & Dec & Jan & Feb & Mar & Apr & May & Jun & \begin{tabular}{c|}
$\#$ \\
colonies
\end{tabular} & $\% \mathrm{~F}$ & $\begin{array}{c}\% \\
\text { Contribution }\end{array}$ \\
\hline Alternaria alternata & 02 & 01 & 11 & 14 & 13 & 10 & 10 & 08 & 04 & 02 & - & - & 75 & 83.33 & 9.34 \\
\hline A.helianthi & - & 03 & 02 & 05 & 06 & - & - & - & - & - & - & - & 16 & 33.33 & 1.99 \\
\hline A.tritici & - & - & - & 06 & 07 & 04 & 05 & - & - & 03 & 03 & 02 & 30 & 58.33 & 3.73 \\
\hline A.soleni & 05 & 05 & 08 & 11 & 12 & 10 & 05 & 02 & - & - & 02 & - & 60 & 75.00 & 7.47 \\
\hline $\begin{array}{l}\text { Aspergillus } \\
\text { fumigatus }\end{array}$ & 03 & 07 & 03 & 09 & 12 & 10 & 03 & - & - & 02 & - & - & 49 & 66.66 & 6.10 \\
\hline A.flavus & 06 & 02 & - & - & 09 & 03 & - & - & 02 & 03 & - & 02 & 27 & 58.33 & 3.36 \\
\hline A.niger & 02 & 01 & 05 & 10 & 16 & 11 & 02 & - & 03 & 05 & 08 & 05 & 68 & 91.66 & 8.46 \\
\hline A.sulphreus & - & 02 & 03 & 05 & 04 & 03 & - & - & 02 & 02 & - & - & 21 & 58.33 & 2.61 \\
\hline A.terreus & - & 02 & - & - & - & - & 02 & 02 & - & - & - & - & 06 & 25.00 & 0.74 \\
\hline A.versicolor & - & - & - & 01 & - & - & - & - & - & - & - & - & 01 & 08.33 & 0.12 \\
\hline Beltrania sp. & 02 & 06 & 06 & 03 & 02 & - & - & - & - & - & - & - & 19 & 41.66 & 2.36 \\
\hline Bipolaris indica & - & 03 & 05 & 11 & 04 & - & - & - & 01 & - & - & - & 24 & 41.66 & 2.99 \\
\hline Candida albicans & - & - & - & - & - & 02 & - & - & - & - & - & 01 & 03 & 16.66 & 0.36 \\
\hline $\begin{array}{l}\text { Cercospora } \\
\text { althacina }\end{array}$ & 02 & - & - & 05 & 05 & 08 & - & - & 01 & 01 & 01 & - & 23 & 58.33 & 2.86 \\
\hline $\begin{array}{l}\text { Cladosporium } \\
\text { clavatum }\end{array}$ & - & 03 & 06 & 03 & 11 & 15 & 09 & - & - & 02 & 02 & - & 51 & 66.66 & 6.35 \\
\hline C.epiphyllum & 02 & 05 & 05 & 10 & 03 & - & - & - & - & 01 & - & - & 26 & 50.00 & 3.23 \\
\hline C.herbarum & - & - & - & - & - & 02 & - & - & - & - & - & - & 02 & 08.33 & 0.24 \\
\hline $\begin{array}{l}\text { Cunninghemella } \\
\text { sp. }\end{array}$ & 04 & 07 & - & - & - & - & - & - & 04 & 03 & - & - & 18 & 33.33 & 2.24 \\
\hline $\begin{array}{l}\text { Curvularia } \\
\text { catenulate }\end{array}$ & 02 & 04 & 06 & 06 & - & - & 02 & 02 & - & - & - & - & 22 & 50.00 & 2.74 \\
\hline C.geniculata & - & 04 & 04 & 09 & 10 & 02 & - & - & - & - & 03 & 04 & 36 & 58.33 & 4.48 \\
\hline C.lunata & 01 & 02 & - & 04 & 07 & 02 & 03 & - & - & - & - & - & 19 & 50.00 & 2.36 \\
\hline C.tetramera & - & - & - & - & 02 & - & - & - & - & - & - & - & 02 & 08.33 & 0.24 \\
\hline Dictyosporium sp. & 01 & - & - & 03 & - & - & - & - & - & - & - & 01 & 05 & 25.00 & 0.62 \\
\hline Drechslera sp. & 02 & 03 & 09 & 11 & 09 & 03 & - & - & - & - & - & 01 & 38 & 58.33 & 4.70 \\
\hline Epicocum sp. & - & - & - & - & 03 & 02 & - & - & - & - & - & 01 & 06 & 25.00 & 0.76 \\
\hline $\begin{array}{l}\text { Fusarium } \\
\text { oxysporum }\end{array}$ & 03 & 02 & - & - & - & - & 02 & 02 & - & - & - & - & 09 & 33.33 & 1.12 \\
\hline $\begin{array}{l}\text { Geotricum } \\
\text { candidum }\end{array}$ & 02 & 04 & - & - & - & - & - & - & - & - & 01 & 01 & 08 & 33.33 & 0.99 \\
\hline Gliocladium sp. & 02 & 03 & - & 02 & 04 & 05 & - & - & - & - & - & - & 16 & 41.66 & 1.99 \\
\hline Mucorsp. & 06 & 07 & 03 & 04 & - & - & 02 & 02 & - & - & - & - & 24 & 50.00 & 2.99 \\
\hline Penicillium citrinum & - & 02 & 06 & 04 & 09 & 10 & 01 & - & - & - & - & - & 32 & 50.00 & 4.95 \\
\hline P. fuscum & - & 02 & 01 & 01 & - & - & - & - & - & - & - & - & 04 & 25.00 & 0.49 \\
\hline Penicillium $s p$. & 01 & - & - & - & - & - & - & - & - & - & - & 01 & 02 & 16.66 & 0.25 \\
\hline Rhizopus nigricans & 04 & 04 & 07 & 02 & 01 & 02 & 04 & - & - & 02 & 02 & 01 & 29 & 83.33 & 3.61 \\
\hline Trichoderma viride & - & 02 & 02 & 06 & - & - & - & - & - & - & 01 & 01 & 12 & 41.66 & 1.41 \\
\hline Unidentified sp. I & 01 & 01 & 01 & - & - & - & - & - & - & - & - & - & 03 & 25.00 & 0.36 \\
\hline Unidentified sp. II & - & - & - & - & 01 & 01 & - & - & - & - & - & - & 02 & 16.66 & 0.25 \\
\hline Mycelia sterilia & - & 02 & 05 & 03 & 02 & - & - & 01 & 01 & - & - & 01 & 15 & 58.33 & 1.86 \\
\hline Total & 53 & 89 & 98 & 148 & 152 & 105 & 50 & 19 & 18 & 26 & 23 & 22 & 803 & & \\
\hline
\end{tabular}


month. Maximum fungal species were found in the months of Aug (27), Oct (25) and Nov (23) and least in the months of Feb (07) and Mar (08).

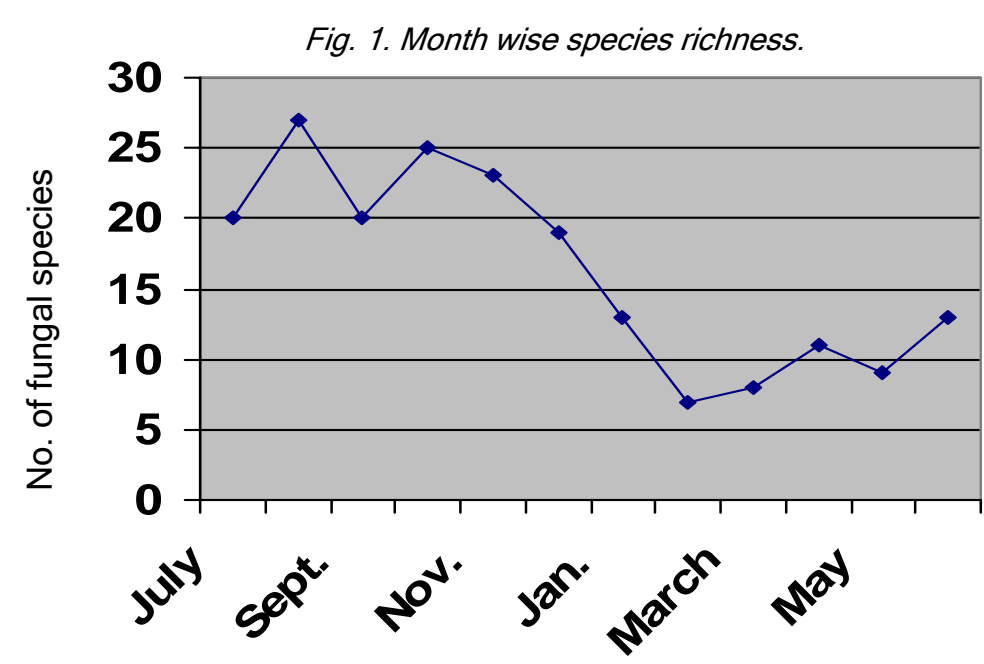

Among the various species encountered, Alternaria alternata was the principal fungi with a contribution of $9.34 \%$ followed by Aspergillus niger (8.46\%) and Alternaria soleni $(7.47 \%)$ respectively. The overall dominance of Aspergillus by 6 species and maximum frequency $(91.66 \%)$ of $A$. niger was observed. This was followed by Alternaria and Curvularia with 4 species each and Cladosporium and Penicillium with 3 species each. Aspergillus was found most predominated genus in the air at Raipur (Tiwari \& Sahu, 1988; Jadhav, 1996; Sahu, 1998; Tiwari et al., 2006).

Although the aeromycoflora was dominated by saprobe, the plant pathogenic and human allergic fungi was also encountered. The study indicates that the incidence of air borne fungal spores of clinical significance show greater variation in response to the environmental conditions. Aspergillus sp. is an opportunistic organism and generally harmless in its normal environment but becomes pathogenic in compromised hosts having lowered resistance. Some of the species of Aspergillus are known to cause aspergilloses. Penicillium, Cladosporium and Curvularia are also considered as important allergenic and mycotoxin producing fungi. The prevalence of these fungi in study site explores potential risk of allergy among residing people. Sawane (2010) done a survey of air borne Penicillium in different environments of Nagpur and concluded its high percentage in the air as a potential risk factor for allergic disorders to people reside nearby. During the investigation it was also observed that the atmosphere of these parks were never free from fungal spores throughout the month. Verma and Khare (2009) studied the aeromycoflora in the houses of allergic patients and suggested such patients to avoid the contact or direct exposure to aeromycoflora.
Vol. 4 No. 5 (May 2011)

ISSN: 0974- 6846

\section{References}

1. Barnett HL, Hunter S and Barry B (1972) Illustrated genera of Imperfect fungi. $3^{\text {rd }}$ edn., Burgess Pub.

2. Begum $J$ and Ahmed K (2006) Aeromycological study of fish, meat and vegetable market. Nature Environ. Pollution Technol. 5(2), 305-307.

3. Ellis MB (1971) Dematiaceous hyphomycetes. Commonwealth mycological institute, Kew, England.

4. Ganguly M (1992) Studies on the incidence of Alternaria in the atmosphere of Bangalore. A major fungal aeroallergen. Ind. J. Aerobiol. 5(1\&2), 30-34.

5. Gilman JC (1959) A manual of soil fungi. Oxford \& IBH Pub. New Delhi.

6. Jadhav SK (1996) Studies of aeromycoflora over rice field at Balodabazar, Raipur. Ph.D. thesis, Pt. R.S. Uni. Raipur.

7. Raha S and Bhattacharya KN (1992) Studies on indoor and outdoor aeromycoflora of Santiniketan, West Bengal with reference to respiratory allergy. Ind. J. Aerobiol. Special vol., 171-178.

8. Rao KSR (1993) Alternaria leaf spot of sunflower II. Meteorological factors associated with disease incidence and atmospheric spore load. Ind. J. Aerobiol. 6(1\&2), 45-48.

9. Sahu K (1998) Aeromycological studies over wheat crop at Raipur (MP), Ph.D. thesis Pt. Ravishankar Shukla Univ., Raipur.

10. Sawane A (2010) A survey of air borne Penicillium in different environment of Nagpur. J. Ind. Bot. Soc. 89(I\&II), 149-154.

11.Singh $\mathrm{NI}$ and Dorycanta H (1992) Aerobiology and crop diseases in Manipur VIII. Fungal aerospora over a maize field in Senapati district. Ind. J. Aerobiol. Special vol., 141-144.

12.Singh L, Vats $P$ and Chaudhary R (2006) Aeromycoflora over transit landfill of Abu Drain at Meerut. Ad. Plant Sci. 19 (I), 147-153.

13.Singh AK and Siddiqui SM (2009) A comparative aeromycological study of unpolluted and polluted air localities. J. Basic Appl. Mycol. 8(I\&II), 109-112.

14.Tilak ST (1998) Aerobiology (biology of airborne organisms) Satyajeet Prakashan, Pune.

15.Tiwari KL and Sahu S (1988) Studies on the leaf surface and air mycoflora of Momordica charantia L. Plant Geobiose New Rep. 7, 135-139.

16. Tiwari KL, Jadhav SK and Kunjam SR (2006) Aeromycoflora of slum area of Raipur (CG) India. $A d$. Plant Sci. 19(II), 387-390

17.Verma K and Chile S (1992) Fungi in the medical college of the Jabalpur city and the allergenic behaviour of some species. J. Ind. Bot. Soc. 71, 247249.

18. Verma KS and Khare D (2009) Aeromycoflora in the houses of allergic patients. J. Basic Appl. Mycol. 8 (I\&II), 117-118.
Research communication

CIndian Society for Education and Environment (iSee)
"Aeromycological profile of public park" http://www.indjst.org
Pragya Kulkarni Indian J.Sci.Technol. 